\title{
MEMAKNAI PEROLEHAN REZKI DALAM HUKUM EKONOMI SYARIAH
}

\author{
Endri Yenti \\ Institut Agama Islam Negeri Bukittinggi,endriyenti22@gmail.com \\ Hasramita \\ Institut Agama Islam Negeri Bukittinggi, basramitaasra@gmail.com \\ Hanif Aidhil Alwana \\ Institut Agama Islam Negeri Bukittinggi, hanif.alwana18@gmail.com
}

\section{(c) (1) (2)}

(C)2020 by the authors. Submitted for possible open access publication under the terms and conditions of the Creative Commons Attribution (CC-BY-SA) license (https://creativecommons.org/licenses/by-sa/4.0/)

dof DOI : 10.30983 /alhurriyah.v5i2.3366

\begin{abstract}
Islam as a religion that has universal teachings, not only talks about aqidah as the main foundation of people in adhering to religion, but also teaches good relations among humans (muamalab). In Islam, the discussion of economics cannot be separated from the concept of sustenance, some people assume that sustenance is identical to property, because economic activity is an activity to fulfill material needs or property (al-Mal) as a life support. Economic activity is an effort to fulfill basic buman needs in order to worship Allah SWT. Therefore, it must be ensured through the rules and methods justified by sharia. Although in principle various types of muamalah are permitted, the concept of usury is strictly not justified in sharia economic law, so it must also be ensured that in meeting daily needs, Muslims must obey these limits and provisions. The method used in this paper is to reveal the meaning of the limitations (arguments) of the Qur'an and Sunnah regarding the acquisition of sustenance then analyzed based on the sociological ethical aspects of Islamic economic law activities. And in this paper the activities of usury and gharar are one of the enemies of Islamic economics in the perspective of Islamic law.
\end{abstract}

Keywords: Rezki, Ethics of Islamic Economic Law, Sharia Economic Law.

\begin{abstract}
Abstrak
Islam sebagai suatu agama yang memiliki ajaran universal, tidak hanya bicara tentang aqidah sebagai pondasi utama umat dalam menganut agama, tapi juga mengajarkan bubungan baik sesama manusia (muamalah). Dalam Islam, bahasan ekonomi tidak terlepas dari konsep reqki, sebagian masyarakat mengasumsikan babwa rezki identik dengan harta, karena kegiatan ekonomi merupakan aktifitas pemenuban kebutuhan material atau harta (al-Mal) sebagai penyangga kehidupan. Aktifitas ekonomi merupakan usaha pemenuban kebutuhan dasar manusia dalam rangka menjalankan ibadab kepada Allah SWT. Oleh karenanya mesti dipastikan melalui aturan dan cara yang dibenarkan syariah. Sekalipun pada prinsipnya, berbagai jenis muamalah dibolehkan. Konsep riba dengan tegas tidak dibenarkan dalam bukum ekonomi syariah, maka harus dipastikan pula dalam pemenuban kebutuhan sehari-hari, umat Islam harus patuh pada batas dan ketentuan tersebut. Metode yang digunakan dalam tulisan ini ialah dengan mengungkap makna batasan (dalil) dari al-Qur an dan Sunnab tentang perolehan reqki, kemudian dianalisis berdasarkan aspek etik sosiologis aktifitas bukum ekonomi Syariah. Dan dalam tulisan ini, aktifitas riba dan gharar menjadi salah satu musub ekonomi dalam persepktif ekonomi syariah.

Kata Kunci: Rezki, Etika Hukum Ekonomi Islam, Hukum Ekonomi Syariah.
\end{abstract}




\section{PENDAHULUAN}

- Dalam Islam bekerja dan berusaha adalah bahagian dari pelaksanaan ibadah, dalam al-Qur'an terdapat ayat-ayat yang memotifasi manusia untuk mengusahakan kehidupan yang lebih baik agar menyempurnakan pelaksanaan ibadah, motifasi itu dapat dipahami dengan merujuk Q.S al-Jumu ah ayat 10, maksudnya "Apabila telah ditunaikan shalat, maka bertebaranlah kamu di muka bumi; dan carilah karunia Allah."

Dari penggalan ayat di atas, dapat dipahami bahwa manusia diperintahkan untuk berusaha (ikhtiar) dalam mengupayakan rezki. Dalam hadis yang diriwiyatkan Bukhari diceritakan bagaimana Rasulullah SAW menyatakan bahwa upaya seseorang untuk mendapatkan rezki dalam bentuk apapun jauh lebih mulia dari pada menadahkan tangan dengan meminta-minta.

Aktifitas pemenuhan kebutuhan dasar manusia adalah bagian dari aktifitas ekonomi, untuk itu pada prinsipnya Islam membolehkan berbagai bentuk usaha, dan segala upaya pemenuhan kebutuhan tersebut, dalam ajaran Islam disebut sebagai konsep rezki. Dalam mendapatkan rezki tersebut umat Islam mesti memahami betul aturan dan cara melakoni aktifitas ekonomi tersebut dengan merujuk ketentuan syariah. ${ }^{1}$ Sehingga dalam tulisan ini akan dibahas mengenai bagaimana konsep rezki dalam Islam, bagaimana Islam memandang aktifitas ekonomi, dan bagaimana etika ekonomi menurut hukum Islam.

\section{Konsep Rezki Dalam Islam}

Berbicara tentang ekonomi, tidak terlepas dari konsep rezki. Sebagian masyarakat mengasumsikan bahwa rezki identik dengan harta (al-mal) sebagai penyangga kehidupan².

Kata al-mal dari segi bahasa diartikan sebagai segala sesuatu yang menyenangkan manusia, baik dalam bentuk materi ataupun dalam bentuk manfaat. ${ }^{3}$ Secara terminologi ulama fiqh mengemukakan berbagai defenisi al-mal diantaranya :

1. Hanafiyyah menyatakan bahwa al-mal adalah "Segala yang diminati manusia dan dapat dihadirkan ketika diperlukan, atau segala sesuatu yang dapat dimiliki dan dimanfaatkan".

2. Kalangan Jumhur menyatakan bahwa al-mal adalah "Segala sesuatu yang mempunyai nilai dan dikenakan ganti rugi bagi yang merusak dan melenyapkannya".

3. Musthafa al-Zarqa' menyatakan bahwa "almal adalah segala yang mempunyai nilai materi dikalangan masyarakat". ${ }^{4}$

Dari ketiga defenisi di atas, dapat dipahamai bahwa kata al-mal adalah sesuatu yang berbentuk materi atau kebendaan yang dapat dimanfaatkan dan memiliki nilai. Karena ada unsur nilai atau harga, maka bagi orang yang merusak benda tersebut dikenakan ganti rugi.

Hakikat kepemilikan harta itu adalah:

1. Allah SWT sebagai pencipta dan pemilik harta yang hakiki.

2. Harta adalah alat/ fasilitas bagi kehidupan manusia.

3. Allah SWT menganugrahkan pemilikan harta kepada manusia. ${ }^{5}$

Sebagai pencipta manusia Allah SWT memberikan fasilitas rezki kepada manusia untuk menjalani kehidupannya dalam berbagai bentuk seperti tumbuhan yang dapat dimanfaatkan manusia sebagaimana

${ }^{2}$ Agil Bahsoan, "Mashlahah Sebagai Maqashid al-Syariah (Tinjauan dalam Perspektif Ekonomi Islam)", Jurnal Inovasi, Vol. 8, No. 1, Maret 2011: 116-117.

${ }^{3}$ Nasrun Harun, Figh Mu'amalah, Jakarta: Gaya Media Pratama, 2007), 73.

${ }^{4}$ Ibid, 75.

${ }^{3}$ M. Sholahuddin, Asas-Asas Ekonomi Islam, (Jakarta: Raja Grafindo Persada, 2007), 41. Jurnal Hukum Islam (JHI) Vol. 9, No. 2, Desember 2011: 241-243. 
disebutkan Allah SWT dalam Q.S al-Baqarah ayat 22 :

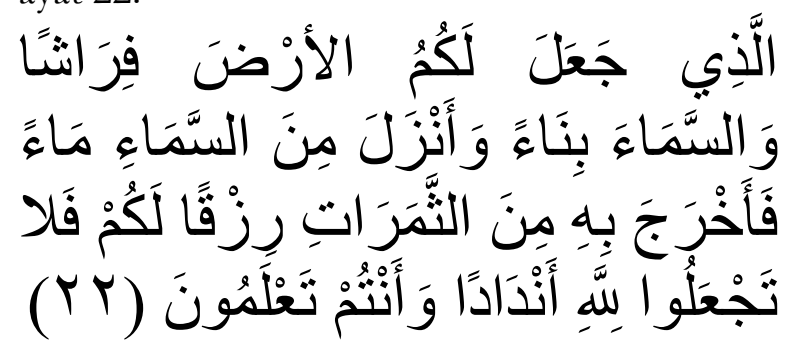

Artinya: "... dan Dia menurunkan air (bujan) dari langit, lalu Dia menghasilkan dengan hujan itu segala buah-buahan sebagai rezki untukmu; ...”.

Pada ayat tersebut dijelaskan bahwa Allah SWT mendatangkan hujan yang dapat menumbuhkan segala macam buah-buahan sebagai salah satu pemberian rezki dari Allah SWT. Apabila dipahami lebih lanjut pada ayat di atas, Allah SW'T juga menyediakan bumi dan langit sebagai hamparan yang apabila manusia mengolahnya dengan baik maka Allah SWT akan memberikan rezki dalam bentuk yang lain.

Mencari rezki berarti berhubungan secara langsung dengan Allah SWT. Hal ini terkait sebagai fungsi Allah SWT dalam aktifitas ekonomi yang dilakukan oleh manusia yaitu sebagai pemberi rezki. Keyakinan itu berpangkal dari konsep ketuhanan yang dimiliki oleh manusia yang memposisikan diri sebagai makhluk. Dengan meyakini bahwa Allah SWT sebagai satu-satunya pemberi rezki akan membebaskan manusia dari tindakan syirik karena menggantungkan dirinya kepada selain Allah SWT. Di dalam Q.S al-Zariyat ayat 58:

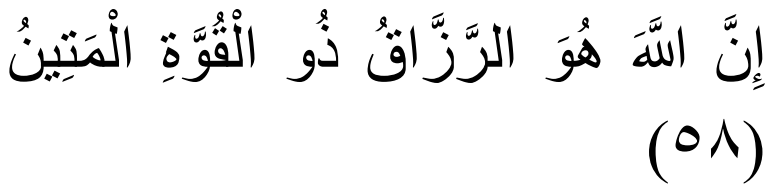

Artinya:"Sesunggubnya Allab SWT Dialab Maba pemberi rezki yang kuat lagi sangat kokoh".

Pemilik hakiki dari segala yang ada di alam adalah Allah SW'T, namun Allah SWT membolehkan dan melindungi seseorang untuk bisa memiliki atau menguasai harta apapun dengan cara apapun asal benar dan halal. Setiap orang baik laki-laki atau perempuan dijamin haknya dalam memiliki harta sebagai akibat hasil usahanya, seperti yang dijelaskan Allah SWT dalam Q.S an-Nisa' ayat 32 :

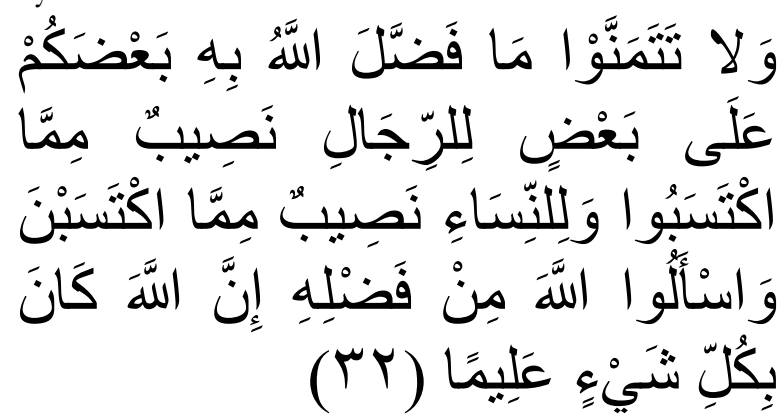

Artinya: "Dan janganlab kamu iri hati terhadap apa yang dikaruniakan Allah SWT kepada sebahagian kamu lebih banyak dari sebabagian yang lain. (Karena) bagi orang laki-laki ada bahagian dari pada apa yang mereka usabakan, dan bagi para wanita (pun) ada bahagian dari apa yang mereka usahakan, dan mohonlah kepada Allah SWT sebagian dari karunianya. Sesunggubnya Allah SWT maha mengetabui segala sesuatu".

Pemilikan seorang terhadap hartanya merupakan amanat, dengan kata lain dia harus menjadikan hak kepemilikan itu membuatnya bertanggung jawab memanfaatkan hartanya untuk kebaikan masyarakat, dan tidak merugikan orang lain. Islam mengatur kepemilikan harta itu dengan sedemikian rupa, seperti perintah mendistribusikan harta tersebut dalam beberapa bentuk tergantung ketentuan yang ditetapkan agama seperti zakat, sedekah, hibah, waris, dll.

Dalam mengusahakan harta, ajaran Islam juga memberikan batasan yang jelas seperti, dibolehkan jual beli dan mengharamkan riba karena dengan riba ada pihak yang terzalimi haknya. Allah SW'T dalam Q.S al-Baqarah ayat 275 menjelaskan:

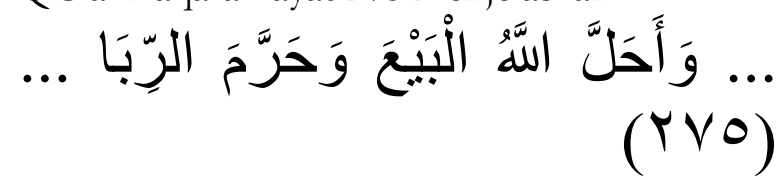

Artinya: “...Allah SWT menghalalkan jual beli dan mengharamkan riba...”.

Selanjutnya ketika usaha mendapatkan harta itu dilakukan melalui bentuk perniagaan, maka Islam memberikan batasan bahwa 
transaksi yang terjadi harus berdasarkan kesepakatan atas dasar kerelaan dan tidak ada unsur paksaan. Pengalihan hak tersebut harus dilakukan dengan cara yang baik agar tidak ada pihak-pihak yang dirugikan akibat transaksi tersebut. Firman Allah SWT dalam Q.S anNisa' ayat 29:

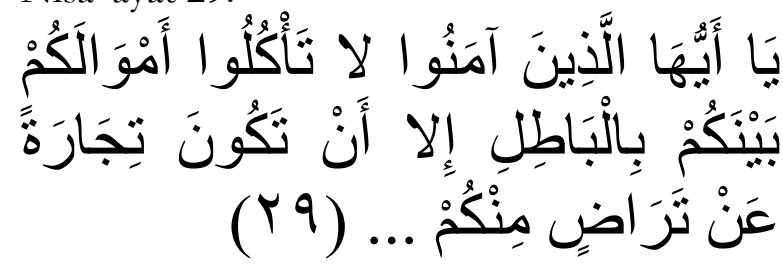

Artinya: "Hai orang-orang yang beriman, janganlah kamu saling memakan harta sesamamu dengan jalan yang bathil, kecuali melalui perniagaan dengan cara suka sama suka di antara kamu. ...".

Allah SWT memberikan rezki kepada manusia dengan tujuan utamanya agar manusia memanfaatkan rezki tersebut sebagai penyangga kehidupan sekaligus agar dapat menjalankan aktifitas utama manusia di dunia dengan beribadah kepada Allah SWT, sebagaimana disebutkan oleh Allah SWT dalam Q.S al-Baqarah ayat 29:

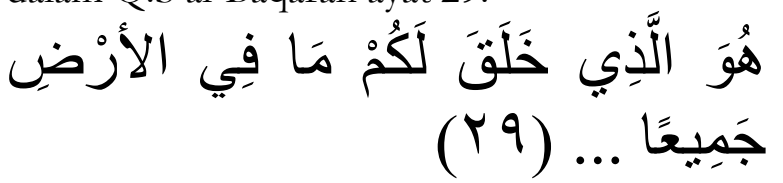

Artinya: "Dialah (Allah SWT), yang menjadikan segala yang ada di bumi untuk kamu ...”.

Dalam mengusahakan rezki Allah SWT memberikan kebebasan dalam memilih cara, selama cara tersebut tidak berbenturan dengan ketentuan agama. Terkait pemanfaatan harta, manusia diberi kewenangan penuh dengan batasan tidak ada pihak-pihak yang terzalimi karena pemanfaatan harta tersebut, seperti yang disebutkan Allah SWT dalam Q.S alBaqarah ayat 188:

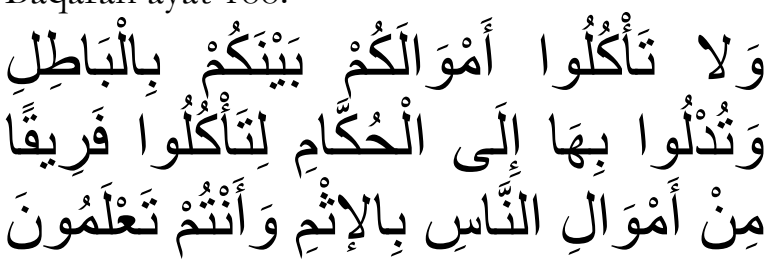

$(1 \wedge \Lambda)$

Artinya: "Dan janganlah sebahagian kamu memakan harta sebabagian lain di antara kamu dengan jalan yang bathil dan (janganlab) kamu membawa (urusan) barta itu kepada hakim, supaya kamu dapat memakan sebahagian dari pada harta benda orang lain itu dengan (jalan berbuat) dosa, padahal kamu mengetabui".

\section{Islam dan Ekonomi}

Mahmud Syaltout seperti yang dinukilkan oleh Nasrun Harun menyatakan bahwa al-Quran dan Hadis mengandung ajaran aqidah dan syariah. Aqidah berkaitan dengan permasalahan aqidah dan keyakinan, sedangkan syariah terbagi lagi kepada ibadah dan muamalah. Permasalahan ibadah berkaitan dengan persoalan-persoalan pengabdian seperti ibadah dan segala bentuknya. Ajaran tentang muamalah berkaitan dengan persoalan hubungan sesama manusia, diantaranya usaha pemenuhan kebutuhan. Usaha ini yang kemudian disebut sebagai aktifitas ekonomi.

Aktifitas ekonomi dalam Islam adalah bagian dari aktifitas muamalah, karena pada prinsipnya ekonomi Islam itu dipahami sebagai usaha merealisasikan kesejahteraan manusia melalui alokasi dan distribusi sumber daya yang sejalan dengan ajaran Islam tanpa membatasi kebebasan individu ataupun menciptakan ketidakseimbangan makro ekonomi.

Aktifitas ekonomi dalam Islam diyakini ada kaitan dengan konsep rezki dari Allah SWT yang merupakan fasilitas yang diberikan Allah SWT kepada manusia. Walaupun rezki tersebut merupakan fasilitas dari Allah SW'T, namun Manusia harus mengusahakannya.

Dalam Islam, ada beberapa hal yang merupakan pokok-pokok pembentukan ekonomi:

1. Adanya kewajiban berusaha

Islam mewajibkan umatnya untuk berusaha dan bekerja, motifasi untuk berusaha itu ditemukan dalam al-Qur'an untuk mengusahakan rezki, seperti yang disebutkan dalam Q.S al-Jumu'ah ayat 10:

${ }^{6}$ Nasrun Harun, Figh Mu'amalah, 41.

Endriyenti, Hasramita, Hanif 

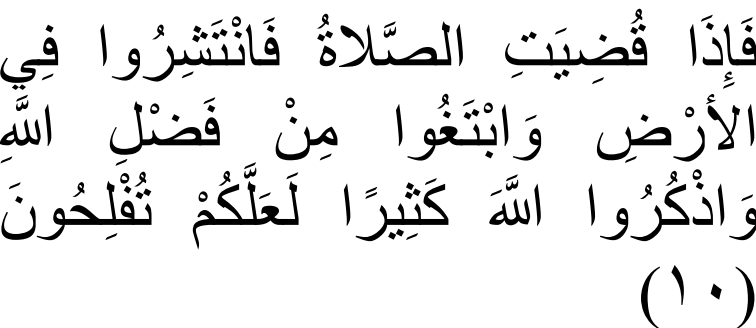

Artinya: "Apabila telah ditunaikan shalat, maka bertebaranlab kamu di muka bumi dan carilah karunia Allah SWT serta perbanyaklah mengingat Allah SWT mudah-mudahan kamu beruntung".

Dari ayat di atas, tergambar bagaimana Islam mengajarkan makna keseimbangan hidup antara kepentingan dunia dan akhirat. Penyeimbangan antara kepentingan dunia dan akhirat merupakan karakteristik ekonomi Islam. Perpaduan antara aspek material dan spiritual tidak ditemukan dalam sistim ekonomi lain, baik kapitalis atau sosialis. ${ }^{7}$

Dalam beberapa hadis, Rasulullah SAW memotifasi manusia untuk berusaha seperti perintah untuk mengusahakan kehidupan dunia seolah manusia itu akan hidup selamanya.

Abdullah Zaki al-Kaaf dalam bukunya Ekonomi Dalam Perspektif Islam menyatakan ada empat hal dalam Islam yang memotifasi umatnya berusaha: ${ }^{8}$

a). Terdapat hadis-hadis Rasulullah SAW yang menjelaskan bahwa bahaya menganggur diantaranya perut besar, banyak tidur dan malas bekerja.

b). Hadis-hadis Rasulullah SAW yang melarang umatnya meminta-minta dengan menggambarkan penderitaan orang tersebut di depan mahkamah Allah SWT.

c). Islam memberikan pengertian bahwa yang dimaksud miskin bukanlah orang yang meminta-minta tapi orang yang telah berusaha tapi tidak mencukupi, karena itu diberikan bantuan melalui zakat.

${ }^{7}$ Nasrun Harun, 32.

${ }^{6}$ Abdullah Zaki al-Kaaf, Ekonomi Dalam Prespektif Islam, (Bandung: Pustaka Setia, 2002), 82.

Endriyenti, Hasramita, Hanif
Terdapat firman Allah SWT yang mencegah sifat putus asa, seperti firman Allah dalam Q.S Yusuf ayat 87:

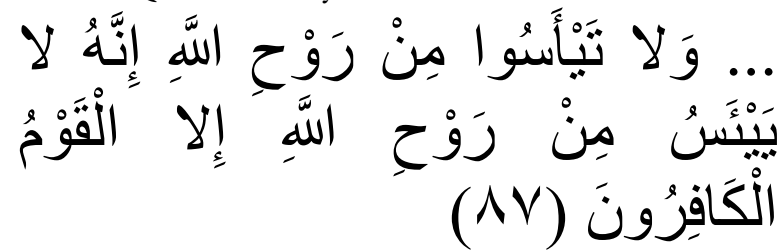

Artinya: "...Dan jangan kamu berputus asa dari rahmat Allah SWT. Sesungguhnya tiada berputus asa dari rahmat Allah SWT, melainkan kaum yang kafir".

Rasulullah SAW juga memberikan motifasi kepada manusia untuk berusaha mendapatkan rezki yang halal, seperti hadis yang diriwayatkan oleh Thabrani dari Ali Ibn Abi Thalib (Sayyid Sabiq, Fiqh Sunnah).

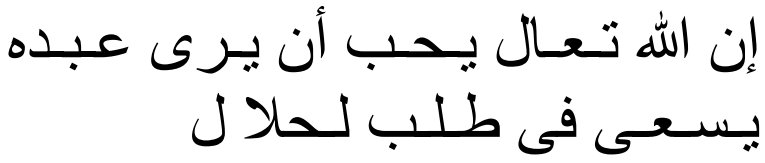

Artinya: "Sesunggubnya Allab SWT suka melibat bambanya berusaba untuk mendapatkan reqki yang halap'.

1. Jaminan Allah SWT bahwa manusia akan mendapatkan apa yang diusahakan

Dalam beberapa firmannya Allah SWT memberikan motifasi untuk melakukan usaha, karena perubahan akan diperoleh manusia dengan berusaha dan ia akan mendapatkan hasil usahanya itu. Firman Allah SWT dalam Q.S an-Najm ayat 39:

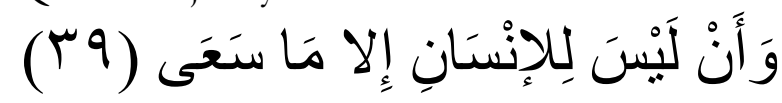

Artinya: "Dan babwasanya seorang manusia tiada memperoleh selain apa yang telah diusahakannya".

Pada ayat lain, Allah SWT melarang manusia berputus asa dengan kemiskinan, sebagaimana firman Allah SWT dalam Q.S alIsra ayat 31 :

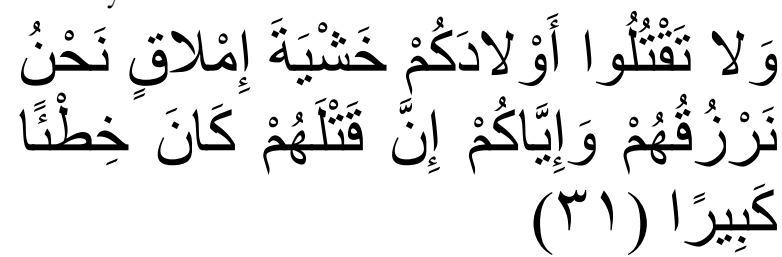

Artinya: "Dan janganlah kamu membunub anakanakmu karena takut miskin ...".

2. Adanya pengakuan hak milik 
Pengakuan hak milik seseorang berdasarkan tenaga dan pekerjaan baik dari hasil sendiri maupun yang diterima melalui warisan. Selain dari dua hal di atas, seseorang tidak boleh mengambilnya kecuali atas keridaan orang yang memiliki, yaitu bisa melalui transaksi jual beli, maupun atas dasar pemberian (hibah). Abdul Wahhab Khallaf seperti yang dikutip oleh Abdullah Zaki alKhaf menyatakan dasar pemindahan hak milik seseorang adalah karena keridhaan. Selanjutnya dia mengajukan ketentuan pemindahan hak milik:

a). Larangan untuk memiliki barangbarang orang lain dengan jalan yang tidak sah.

b). Menghukum orang-orang yang mencuri, merampas, dan mengambil barang orang yang bukan miliknya secara tidak sah.

c). Larangan menipu dalam jual beli dan membolehkan khiar.'

3. Pemanfaatan harta untuk kepentingan agama dan kesejahteran masyarakat.

Islam mengajarkan bahwa harta yang dimiliki seseorang walaupun diusahakan sendiri dengan cara yang seharusnya, tetap harus dikeluarkan sebagiannya karena di dalamnya terdapat hak orang miskin yang telah berusaha, tapi yang mereka dapatkan tidak mencukupi kebutuhannya seperti melalui zakat atau sedakah yang tujuannya adalah untuk mensucikan pemilik harta. Firman Allah SWT dalam Q.S at-Taubah ayat 103:

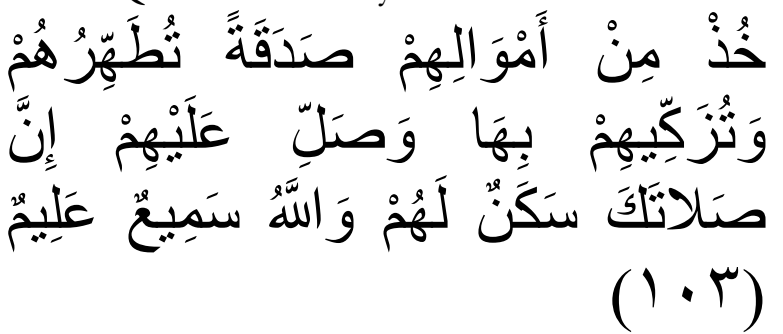

Artinya: "Ambillah zakat dari sebagian harta mereka, dengan zakat itu kamu membersibkan dan mensucikan mereka dan mendoalah untuk mereka. Sesunggubnya doa kamu itu menjadi ketenteraman

${ }^{9}$ Abdullah Zaki al-Kaaf, Ekonomi Dalam Prespektif Islam, 82.

Endriyenti, Hasramita, Hanif jiwa bagi mereka, dan Allah SWT maha mendengar lagi maha mengetahui”.

Yang dimaksud "mensucikan" pada ayat tersebut adalah untuk membersihkan diri orang yang berzakat dari sifat kikir dan rasa cinta berlebihan terhadap harta yang dapat merusak akidah. Di samping itu, zakat merupakan salah satu usaha pendistribusian harta agar tidak menumpuk pada orang-orang tertentu.

Beberapa hal di atas merupakan cikal bakal terbentuknya konsep aktifitas ekonomi dalam Islam. Selanjutnya, pembahasan tentang ekonomi dan muamalah dalam Islam terdapat empat sendi utama, yaitu: ketuhanan, etika, kemanusiaan, dan sikap pertengahan (keseimbangan), keempat sendi tersebut merupakan ciri khas ekonomi Islam yang diberlakukan dalam segala aktifitas kehidupan manusia.

a). Norma ketuhanan dalam ekonomi Islam.

Ekonomi Islam meyakini bahwa titik awal konsep dari ekonomi Islam adalah fasilitas rezki yang diberikan Allah SWT dan bertujuan akhir kepada Allah SWT, sesuai ketentuan syariat Islam. Apapun aktifitas ekonomi yang dilakukan dari bentuk yang paling sederhana seperti bertani sampai kepada yang paling modern, dilakukan dalam bingkai pengabdian kepada Allah SWT, sesuai tujuan utama penciptaan manusia ke permukaan bumi. Hal tersebut terdapat dalam firman Allah SWT Q.S al-Zariyat ayat 56:

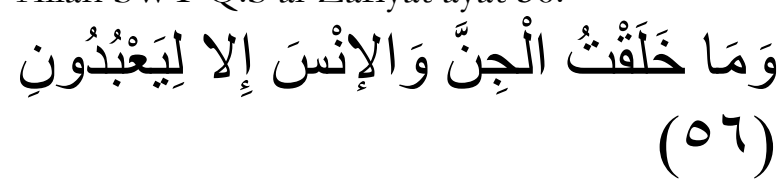

Artinya: "Dan aku tidak menciptakan jin dan manusia melainkan supaya mereka mengabdi kepadaku".

Nilai ketuhanan dalam ekonomi Islam melahirkan norma istikblaf yang menyatakan bahwa apa yang dimiliki manusia hanyalah titipan. Seorang muslim mesti percaya bahwa Ia bekerja dimuka bumi ini dengan kekuatan dari Allah SWT, dan melalui sarana dari Allah 
SWT. Manusia bekerja sesuai hukum kausalitas, dan ini perbuatan Allah SWT. Maka apabila manusia memperoleh harta, itu adalah harta Allah SWT yang dititipkan kepada manusia karena Dialah pemilik harta yang sejati (hakiki). ${ }^{10}$

Konsep istikhlaf ini muncul berdasarkan beberapa firman Allah SWT diantaranya:

a). Q.S an-Najm ayat 31

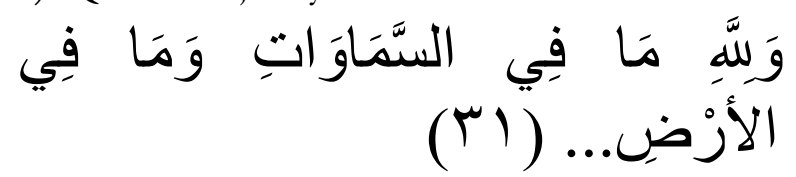

Artinya: "Dan banya kepunyaan Allah SWT apa yang ada di langit dan apa yang ada di bumi...".

b). Q.S az-Zumar ayat 62

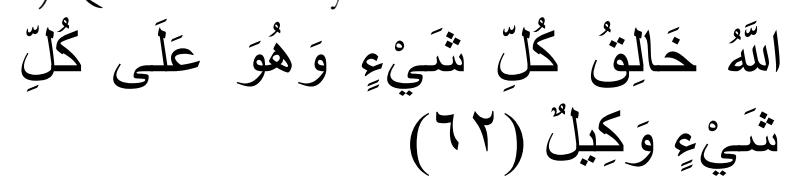

Artinya: "Allah SWT menciptakan segala sesuatu dan dia memelihara segala sesuatu".

c). Q.S Yunus ayat 66

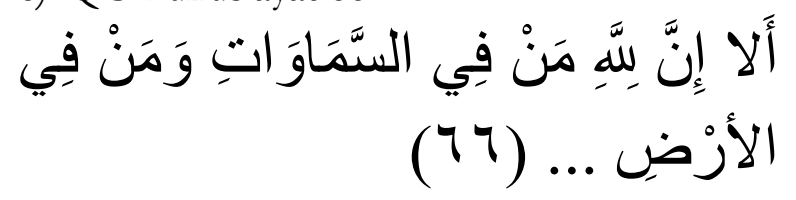

Artinya: "Ingatlah, sesungguhnya kepunyaan Allah SWT semua yang ada di langit dan semua yang ada di bumi...”.

Pemikiran istikblaf memberikan efek positif terhadap sistim perekonomian dan sosial umat Islam seperti mengurangi sikap sombong dan bangga terhadap harta yang dimiliki, menimbulkan keinginan membagikan harta tersebut kepada orang yang dianggap membutuhkan dan hal lain yang sangat penting adalah memanfaatkan harta tersebut dengan ketentuan dan batasan dari pemilik harta yang sebenarnya yaitu Allah SWT. ${ }^{11}$

b). Norma dalam ekonomi Islam.

${ }^{10}$ Yusuf Qardhawi, Norma dan Etika Ekonomi Islam, Judul Asli: Daur al-Qayyim wa al-Akblaq fi alIqtishadi al-Islami, Penterjemah: Zainal Arifin (Jakarta: Gema Insani, 1995).

${ }^{11}$ Fahmi Medias, "Wakaf Produktif Dalam Perspektif Ekonomi Islam", Jurnal Ekonomi Islam, Vol. IV, No.1, Juli 2010, 81-82.

Endriyenti, Hasramita, Hanif
Yang membedakan konsep Islam dengan paham materialism dalam konteks ekonomi adalah bahwa Islam menggabungkan antara perilaku ekonomi dan etika. Seluruh aktifitas kehidupan umat Islam dibingkai dengan norma. Ajaran Islam telah membekali umatnya dengan risalah yang diturunkan oleh Allah SWT kepada Rasulnya agar dapat membenahi akhlak (perilaku) manusia.

Umat (kaum) muslim secara individu diberi kebebasan dalam melakoni aktifitas ekonomi untuk mendapatkan keuntungan, namun di sisi lain, umat Islam juga inheren (terikat) dengan iman dan etika, sehingga manusia tidak bebas secara muthlaq (tanpa batasan) dalam menginfestasikan, mengelola modalnya, dan membelanjakan hartanya. Seperti Allah SWT melarang jual beli khamar, sekalipun mendatangkan untung yang besar. Meminum khamar dapat melemahkan fungsi saraf dan saat itu manusia tidak mampu lagi mengendalikan diri sehingga melakukan halhal yang berbenturan dengan etika.

Dalam bertransaksi, Islam mementingkan adanya kerelaan. Hal ini tergambarkan dengan adanya khiar dalam jual beli. Islam sangat menganjurkan melakukan aktifitas ekonomi dengan cara-cara yang baik sehingga tidak ada pihak-pihak yang dirugikan. Salah satu bentuk aktifitas ekonomi Islam ialah adanya larangan menjual barang yang dijual orang lain. Hal itu dapat dirujuk pada hadis Rasulullah SAW yang diriwayatkan oleh Nasa'i dari Ibn Umar: ${ }^{12}$

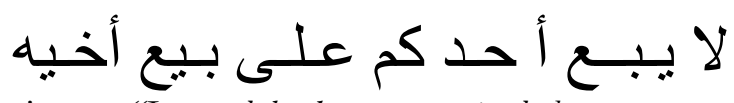

Artinya: "Janganlah kamu menjual barang yang telah dijual oleh saudaramu".

Para pakar ekonomi non-muslim mengakui keunggulan Islam dalam menggabungkan etika dan ekonomi. Seperti yang diungkapkan oleh Jack Austri dalam bukunya Islam dan Pengembangan Ekonomi. Ajaran Islam adalah gabungan antara tatanan 
kehidupan praktis dan sumber etika yang mulia, antara keduanya terdapat ikatan yang sangat erat, kemudian ekonomi yang kekuatannya berdasarkan wahyu dari langit tidak diragukan lagi, pastilah ekonomi yang berdasarkan etika. ${ }^{13}$

c). Norma kemanusiaan dalam ekonomi Islam

Dalam konsep ekonomi Islam, manusia dan faktor kemanusiaan merupakan unsur penting. Faktor kemanusiaan dalam konsep ekonomi Islam ialah kumpulan (akumulasi) etika yang terdapat dalam al-Qur'an dan Hadis. Etika ajaran Islam mengajarkan manusia untuk bekerja sama/tolong-menolong (taawun), menjauhkan sikap iri dengki dan dendam.

Salah satu ciri kemanusiaan dalam ekonomi Islam ialah peyediaan sarana yang baik untuk manusia. Islam menganjurkan manusia bekerja dan berusaha, kemudian manusia akan mendapatkan hasil sesuai besaran (ikhtiar) yang ia usahakan. Menurut teori Islam, kehidupan terbagi dua unsur yaitu unsur materi dan spiritual. ${ }^{14}$

Manusia dapat menikmati berbagai rezki yang disediakan Allah SWT di bumi dalam berbagai bentuk, seperti tumbuhan, binatang ternak, barang tambang yang bisa dijadikan perhiasan, dll. Disamping itu, Allah SWT juga menciptakan berbagai keindahan yang dapat dimanfaatkan manusia dalam batas-batas yang dihalalkan dan menjauhkan dari apa-apa yang diharamkan Allah SWT.

Kebahagiaan tidak hanya dari ukuran materi yang dimiliki seseorang, sesungguhnya fondasi keempat bahagiaan itu terletak pada kedamain, kelapangan dada, dan ketenangan hati. Oleh karena itu, jika manusia menginginkan kebahagian, maka sesungguhnya ia tidak akan terlalu fokus memperolehnya dengan mengumpulkan harta sebanyakbanyaknya. Karena betapa banyak manusia memiliki limpahan harta, tapi tak dapat menikmati karena sakit atau sebagainya seperti

\footnotetext{
${ }^{13}$ Yusuf Qardhawi, 55.

14 Yusuf Qardhawi, 58.
}

Endriyenti, Hasramita, Hanif yang dialami Karun yang diperbudak oleh harta, yang pada akhirnya, harta itu pula yang menghancurkannya.

d). Norma keseimbangan dalam ekonomi Islam

Salah satu sendi utama ekonomi Islam adalah sifatnya yang pertengahan dan keseimbangan. ${ }^{15}$ Hal ini terlihat jelas pada sikap Islam terhadap hak individu dan masyarakat yang diletakkan dalam neraca keseimbangan antara dunia dan akhirat. Islam tidak condong kepada paham yang menolak dunia secara mutlak yang menganggap dunia sumber kejahatan yang harus ditinggalkan. Islam juga tidak condong kepada paham yang menjadikan dunia sebagai tujuan akhir seperti yang dianut kalangan kaum materialism dan hedonism. Dalam ajaran Islam, kehidupan dunia adalah jalan menuju tempat yang lebih kekal. Karena dunia merupakan jalan, maka ia dibuat sedemikian rupa agar manusia yang melewatinya merasa aman dan sampai ketujuan dengan selamat.

Islam menganggap kehidupan ekonomi yang baik sebagai suatu rangsangan dan sarana untuk berhubungan dengan Allah SWT. Dalam hal ini, Islam memperhatikan permasalahan yang berkaitan dengan harta, karena merupakan sarana memperoleh kebaikan. Islam juga tidak memandang harta dan kekayaan sebagai penghalang untuk mencari derajat yang tertinggi dan taqarrub kepada Allah SWT, karena miskin bukan simbol manusia taqwa seperti yang dipahami kalangan sufisme. ${ }^{16}$

Dalam al-Qur'an kata khairan diidentikkan dengan harta, seperti yang terdapat dalam Q.S al-Baqarah ayat 215:

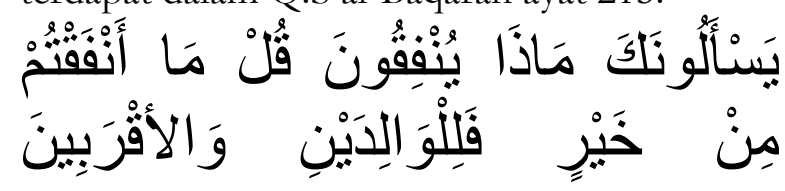

${ }^{15}$ Naerul Edwin Kiky Aprianto, "Kebijakan Distribusi Dalam Pembangunan Ekonomi Islam”, Jurnal Al-Amwal, Vol. 8, No. 2 Tahun 2016, 438-440.

${ }^{16}$ Yusuf Qardhawi, 74. 


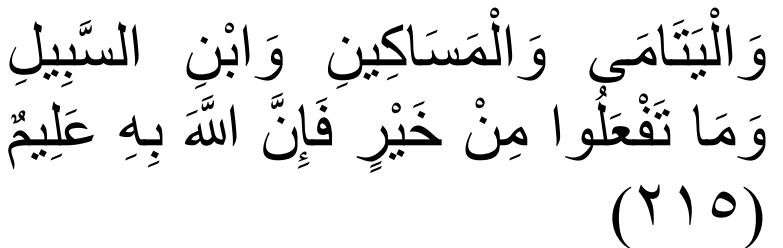

Artinya: "Mereka bertanya tentang apa yang mereka nafkeabkan? katakanlab: "Apa saja harta yang kamu nafkabkan bendaklah diberikan kepada ibubapak, kaum, anak-anak yatim, orang-orang miskin dan orang-orang yang sedang dalam perjalanan", dan apa saja kebaikan yang kamu buat, maka Allah SWT Maha mengetahui".

Al-Thabari juga mengartikan kata "khair" dalam ayat tersebut dengan harta. Ayat tesebut merupakan jawaban dari pertanyaan beberapa sahabat yang memiliki harta, maka Rasulullah SAW menjawab pertanyaan para sahabat dengan firman Allah SWT di atas, bahwa apabila seseorang memiliki hartanya hendaklah ia menafkahi orang tuanya, karib kerabat, anak yatim, dan Ibn sabil. Nafkah yang dimaksud bukan zakat karena ketika ayat tersebut turun, zakat belum disyariatkan. ${ }^{17}$

Rasulullah SAW dalam beberapa hadisnya juga menjelaskan bagaimana orang yang memiliki kekayaan merupakan sarana untuk mendapatkan kebaikan, ketika kekayaan tersebut dimanfaatkan untuk mencari ridha Allah SWT. Untuk itu, manusia dianjurkan mengusahakan kekayaan tersebut agar mendapatkan kebaikan. Hadis yang diriwayatkan oleh Muslim dari Ibn Mas'ud:

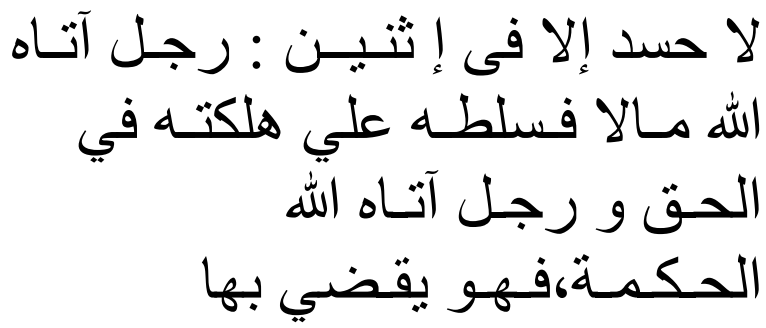

Artinya: "Tidak boleh dengki kecuali pada dua hal, orang yang orang diberikan Allab SWT barta kemudian ia belanjakan untuk berbuat

${ }^{17}$ Abu Ja 'far al-Thabari, Jami’ al-Bayan fi Ta'wi al-Qur'an, (Beirut: Mu'assasah al-Risalah, 2000). Lihat juga al-Alusi, Rubul Ma'ani fi Tafsir alQur'an al-Azim ,(Maktabah al-Syamilah).

Endriyenti, Hasramita, Hanif kebaikan dan yang diberikan Allab SWT ilmu lalu dilaksanakan dan diajarkan".

Islam menempatkan unsur materi sebagai penyeimbang unsur spiritual agar manusia bisa meningkatkan taraf hidupnya agar dapat mencapai tujuan akhir yang sebenarnya yaitu kebahagiaan diakhirat, karena pada dasarnya kekayaan akan bisa dijadikan sarana melakukan kebaikan apabila kekayaan tersebut dimanfaatkan sesuai ketentuan syariat.

\section{Etika Ekonomi Dalam Hukum Islam}

Etika ialah cabang ilmu filsafat yang mempelajari baik buruknya perilaku manusia. Sehingga etika ${ }^{18}$ dalam artian ini sering juga disebut "filsafat praktis". Apabila ditambah dengan ekonomi/ bisnis, maka etika ekonom adalah sebuah filsafat praktis yang membahas aktifitas ekonomi/ bisnis. ${ }^{19}$

Etika dalam aktifitas ekonomi mengkaji dimensi lain dari kehidupan manusia, seperti politik, budaya, sosial dan lain sebagainya. Maksudnya etika belum merupakan suatu topik tersendiri, ia masih sebagai cabang satu topik ekonomi/ bisnis. Kemudian pada tahun 1970-an muncullah etika ekonomi sebagai satu topik tersendiri dan terlepas dari kerangka topik ekonomi/ bisnis.

Joan Robinson, yang juga dikutip oleh Ibrahim Warde, mensyaratkan tiga hal untuk suatu sistem ekonomi, yaitu memiliki aturan, ideologi, dan suara hati individu agar sampai pada arah tujuan, inilah yang disebut sebagai dimensi etis (etika).

Sistem etik dalam ekonomi Islam yang berbasiskan syariah menekankan produk, kewajaran, dan kejujuran di dalam perdagangan, serta kompetisi yang adil. Hal ini

${ }^{18}$ Ida Martinelli, "Menelisik Dimensi Etika Dalam Kegiatan Ekonomi Menurut Perspektif Islam”, Jurnal Edu Tech, Vol. 4 No.1 Maret 2018, 40.

${ }^{19}$ Efa Rodiah Nur, "Riba Dan Gharar: Suatu Tinjauan Hukum Dan Etika Dalam Transaksi Bisnis Modern", Jurnal al-'Adalah, Vol. XII, No. 3, Juni 2015, 656-660. 
dengan merujuk pada Q.S 17 ayat 35, 26 ayat 181-183, 104 ayat 2-4.

Tentang etika ini, yang menjadi dasar fundamental sebagai batas bagi ajaran Islam adalah yang disebutkan dalam Q.S al-Baqarah ayat 275 bahwa "Allah telah menghalalkan jual beli dan mengaharamkan riba". Kemudian apabila dijabarkan, larangan riba itu terbagi pada tiga hal, yaitu: riba secara tidak wajar, eksploitasi, dan tidak produktif.

Bunga dalam riba menurut pandangan tradisional mendasarkan hubungan antara pemberi pinjaman dan peminjam. Maksudnya, apabila peminjam mengalami kerugian ataupun mendapat keuntungan, peminjam yang menanggung semua kerugian atau mendapatkan keuntungan. Sedangkan pemberi pinjaman, ia tetap mendapatkan keuntungan tanpa tergantung dengan hasil bisnis yang dispekulasikan tersebut. Pandangan ini dibantah oleh Islam dengan konsep bahwa kerugian transaksi yang dilakukan peminjam dapat ditanggung secara bersama dengan kesepakatan oleh kedua belah pihak, sehingga dalam bahasa lain ajaran hukum Islam menolak gharar yang bersifat spekulatif. ${ }^{20}$

Dalam pandangan etika, dilarangnya melakukan riba ialah karena akan mengeksploitasi satu pihak. Sehingga dalam aktifitas ekonomi, hal ini tentunya akan merugikan satu pihak dan menguntungkan pihak lain. Pelarangan riba, agar tidak ada pihak-pihak yang sedang bertransaksi dirugikan, di samping itu, agar uang tidak menjadi komoditas, tetapi sebagai alat tukar yang menghasilkan barang.

Hal yang sama juga ditengarai pada hukum gharar. Secara etika, dilarangnya gharar ialah karena tidak etis melakukan transaksi yang belum jelas dan mengandung ketidakpastian bagi kedua belak pihak. Secara ekonomi, hal ini akan merugikan satu pihak

${ }^{20}$ Adiwarman A. Karim dan Oni Sahroni, Riba, Gharar dan Kaidah-kaidah Ekonomi,(Jakarta: Raja Grafindo Persada, 2015), 82-83.

Endriyenti, Hasramita, Hanif dan menguntungkan pihak lain. Pelarangan gharar dimaksudkan untuk memberikan perlindungan bagi pihak-pihak yang bertransaksi dalam aktifitas ekonomi. Hikmah terpenting dilarangnya gharar ialah agar tidak terjadi perselisihan dan permusuhan di antara yang bertransaksi.

Mesti dicermati bahwa Islam melarang riba dan gharar dikarenakan keduanya merupakan suatu sikap yang menyalahi nilai-nilai yang telah ada dalam Islam itu sendiri, baik itu dari segi etika, moral dan akhlak. Secara umum, nilai-nilai etika Islam dirangkum dalam empat prinsip pokok: ${ }^{21}$ Pertama, tauhid. Maksudnya ialah prinsip ini dapat mengantarkan manusia mengakui Keesaan Allah SWT, dengan konsekuensi keyakinan bahwa segala sesuatu yang berasal dan kesudahannya kembali kepada Allah SWT. Sehingga prinsip ini menghasilkan kesatuan kemanusiaan, kesatuan alam raya, kesatuan dunia, dan akhirat.

Kedua, etika keseimbangan (al-musawat). Maksudnya prinsip ini akan mengantarkan umat Islam meyakini segala sesuatu diciptakan Allah SWT dalam keadaan seimbang dan serasi. Sebagaimana disebutkan dalam Q.S. alMulk ayat 3.

Ketiga, kehendak bebas (al-burriyat), etika ini merupakan prinsip yang mengantarkan umat Islam meyakini bahwa Allah SWT memiliki kebebasan mutlak dan juga memberikan kebebasan itu kepada manusia untuk memilih jalannya sendiri, baik itu yang baik ataupun yang buruk. Keempat, etika tanggung jawab (al'ad), ialah atas kebebasan manusia sebagai individu dan kolektivitas merekalah yang menentukan nasibnya sendiri, tapi harus sesuai dengan kaidah-kaidah Islam.

Kelima, etika tolong menolong (at-Ta awnn) dan toleransi (at-Tasamub). Maksudnya ialah aktifitas ekonomi yang berorientasi pada hubungan muamalah yang paripurna dengan tidak hanya melakukan aktifitas ekonomi semata untuk mendapatkan keuntungan sendiri (kapitalism), akan tetapi juga

\footnotetext{
${ }^{21}$ Efa Rodiah Nur, Riba Dan Gharar: Suatu Tinjauan Hukum Dan Etika Dalam Transaksi Bisnis Modern, ..., 659.
} 
mempunyai orientasi berbagi dan memberikan kemuduhan kepada sesama manusia dalam melakoni aktifitas ekonomi. ${ }^{22}$

\section{KESIMPULAN}

Dari paparan di atas dapat dipahami bahwa kajian ekonomi dalam Islam adalah bagian dari penerapan konsep muamalah sebagai bagian dari ajaran Islam. Aktifitas muamalah meliputi persoalan-persoalan hubungan sesama manusia dalam usaha pemenuhan kebutuhan manusia, sesuai ajaran Islam berdasarkan prinsip-prinsip yang dikandung dalam al-Qur'an dan hadis.

Islam memberikan kebebasan kepada umatnya untuk melakukan aktifitas ekonomi, karena dalam Islam kekayaan itu adalah sarana untuk penyempurnaan ibadah. Harta dapat dijadikan wadah untuk melakukan kebaikan apabila dimanfaatkan sesuai aturan agama sehingga dengan konsep ekonomi yang demikian, akan memberikan pertumbuhan dan inovasi kemaslahatan terhadap hubungan manusia, baik secara individu, kelompok, atau secara berbangsa atau bernegara.

\footnotetext{
${ }^{22}$ Aris Baidowi, Etika Bisnis Perspektif Islam, Jurnal Hukum Islam (JHI) 9, no.2 (Desember 2011), 245. 


\section{DAFTAR KEPUSTAKAAN}

Al-Alusi. Rubul Ma'ani fi Tafsir al Qur'an al-Ażim. Maktabah al-Syamilah.

Al-Kaaf, Abdullah Zaki. 2002. Ekonomi Dalam Prespektif Islam. Bandung: Pustaka Setia.

Al-Naisaburi, Abu Husain Muslim Ibn Hajjaj al-Kusairi. 2007. Shabih Muslim. Beirut: Dar al-Fikri.

Al-Thabari, Abu Ja'far. 2000. Jami' al-Bayan fi ta'wi al-Qur'an. Beirut: Mu'assasah al-Risalah.

Aprianto, Naerul Edwin Kiky. 2016. Kebijakan Distribusi Dalam Pembangunan Ekonomi Islam. Jurnal Al-Amwal. Vol. 8. No. 2.

Bahsoan, Agil. 2011. Mashlahah Sebagai Maqashid al-Syariah (Tinjanan dalam Perspektif Ekonomi Islam), Jurnal Inovasi. Vol.8. No.1.

Baidowi, Aris. 2011. Etika Bisnis Perspektif Islam, Jurnal Hukum Islam (JHI) Vol.9, No.2, Desember.

Harun, Nasrun. 2007. Fiqh Mu'amalah. Jakarta: Gaya Media Pratama.

Iskandar, Azwar, Khaerul Aqbar. 2019. Reposisi Praktik Ekonomi Islam: Studi Kritis Praktik Ekonomi Islam Di Indonesia. Jurnal Nukhbatul 'Ulum: Bidang Kajian Islam Vol. 5. No.1.

Karim, Adiwarman A dan Oni Sahroni. 2015. Riba, Gharar dan Kaidah-kaidah Ekonomi. Jakarta: Raja Grafindo Persada.

Karim, Azwar Adiwarman. 2004. Sejarah Pemikiran Ekonomi Islam. Jakarta: Raja Grafindo Persada.

Lubis, Ibrahim. 1994. Ekonomi Islam Suatu Pengantar. Jakarta: Kalam Mulia.

Martinelli, Ida 2018. Menelisik. Dimensi Etika Dalam Kegiatan Ekonomi Menurut Perspektif Islam. Jurnal Edu Tech Vol. 4 No.1 Maret.

Medias, Fahmi. 2010. Wakaf Produktif Dalam Perspektif Ekonomi Islam. Jurnal Ekonomi Islam. Vol. IV. No.1.

Mulyani, Sri. 2020. Pentingnya Ekonomi Syariah Bagi Perekonomian Global. Jakarta: Tempo.

Nur, Efa Rodiah. 2015. Riba Dan Gharar: Suatu Timjauan Hukum Dan Etika Dalam Transaksi Bisnis Modern. Jurnal al-'Adalah Vol. XII. No. 3. Juni.

Qardhawi, Yusuf. 1995. Norma dan Etika Ekonomi Islam, Judul Asli: Daur al-Qayyim wa al-Akblaq fi al-Iqtishadi al-Islami, Penterjemah: Zainal Arifin. Jakarta: Gema Insani.

Sabiq, Sayyid. Fiqh Sunnah. Beirut: Dar al-Fikri. Tt.

Sholahuddin. 2007. M. Asas-Asas Ekonomi Islam, Jakarta: Raja Grafindo Persada. 